\title{
Analisis Efektivitas Biji dan Daun Kelor (Moringa oleifera) Untuk Penjernihan Air
}

\author{
Ariyatun $^{*}$, Puji Ningrum1, Musyarofah', Nurul Inayah1 \\ 1Program Magister Pendidian Kimia Universitas Negeri Semarang, Indonesia \\ *Email: ariyatun2017@students.unnes.ac.id
}

\begin{abstract}
s
Penelitian ini untuk menganalisis keefektifan bahan dari biji dan daun kelor (Moringa oleifera) yang digunakan sebagai koagulan. Pada penelitian ini mengambil sampel satu liter air sungai yang keruh untuk setiap percobaan. Sebelumnya air diukur dahulu dengan turbidimeter. Berdasarkan hasil penelitian penjernihan Air sungai dengan bubuk biji kelor didapatkan hasil 8,67 NTU untuk bubuk biji kelor 0.5 gram, 4.29 NTU untuk biji kelor 0.2 gram dan 3.07 NTU dengan biji kelor 0.1 gram. Hal ini artinya dalam praktikum penjernihan air dengan bubuk biji kelor yang telah dilakukan kualitas air bertambah jernih dan masih memenuhi persyaratan air bersih yang diperbolehkan. Dapat disimpulkan pula bahwa dalam penjernihan air 1 liter lebih efektif / idealnya dengan 0.1 gram bubuk biji kelor.
\end{abstract}

Kata kunci : biji dan daun; moringa oleifera; koagulan

\section{Pendahuluan}

Air adalah kebutuhan dasar bagi kehidupan, karena kehidupan manusia sangat bergantung pada air, terutama adanya air bersih. Mulai dari penggunaan untuk kebutuhan rumah tangga antara lain; mencuci, mandi, minum, industri, dan pertanian. Banyak wilayah Indonesia yang menderita kekeringan rutin tiap tahunnya, bahkan banyak pula yang krisis air bersih.

Dalam sistem penyediaan air bersih, sumber air merupakan satu komponen yang mutlak harus ada, karena tanpa sumber air sistem penyediaan air tidak akan berfungsi, dengan mengetahui akan karakteristik masing-masing sumber air serta faktor-faktor yang mempengaruhinya, diharapkan dapat membantu di dalam pemilihan air baku untuk suatu sistem penyediaan air bersih, serta mempermudah tahapan selanjutnya di dalam pemilihan tipe dari pengolahan untuk menghasilkan air yang memenuhi standar kualitas secara fisik, kimiawi dan bakteriologis (Nugrahayu dan Purnomo, 2013).

Air sungai merupakan sumber air baku yang melimpah dibandingkan sumber air baku yang lain, seperti halnya air tanah yang volumenya dipengaruhi oleh musim, jika musim kemarau ketersediaan air terbatas dan juga sebaliknya jika musim hujan ketersediaan air melimpah (Chandra, 2015).

60 
Pengolahan air dilakukan pada air baku yang tidak memenuhi standar kualitas air bersih, sehingga unsur yang tidak memenuhi standar perlu dihilangkan ataupun dikurangi, agar seluruh air memenuhi standar yang berlaku (Dinora dan Purnomo, 2013). Salah satu alternatif yang tersedia secara lokal adalah penggunaan koagulan alami dari tanaman yang barangkali dapat diperoleh di sekitar kita. Penelitian dari The Environmental Engineering Group di Universitas Leicester, Inggris, telah lama mempelajari potensi penggunaan berbagai koagulan alami dalam proses pengolahan air skala kecil, menengah, dan besar. Penelitian mereka dipusatkan terhadap potensi koagulan dari tepung biji tanaman kelor atau Moringa oleifera.

Pohon kelor diketahui mengandung polielektrolit kationik dan flokulan alamiah dengan komposisi kimia berbasis polipeptida yang mempunyai berat molekul mulai dari 6000 sampai 16000 dalton, mengandung hingga 6 asam-asam amino terutama asam glutamat, mentionin dan arginin (Jahn, 1986). Sebagai bioflokulan, biji kelor kering dapat digunakan untuk mengkoagulasiflokulasi kekeruhan air (Utami, et. al., 2013).

Penjernihan air dengan biji kelor dapat dikatakan sebagai penjernihan air dengan bahan kimia, karena tumbukan halus biji kelor dapat menyebabkan terjadinya gumpalan (koagulan) pada kotoran yang terkandung dalam air. Proses penjernihan air ini memakai metode koagulasiflokulasi.

Pohon kelor merupakan tanaman yang biasa dimanfaatkan sebagai sayuran. Bagian dari pohon kelor yang biasa digunakan sebagai sayur, yaitu daun dan buah kelor. Adapun buah kelor yang digunakan yang masih muda, dan tidak dapat dijadikan sayuran lagi apabila telah tua dan kering (Fauzi, 2010). Selain itu, tanaman kelor juga dapat dimanfaatkan sebagai obat untuk menurunkan kadar gula darah dan juga obat cacingan (Sada \& Tanjung, 2010). Berdasarkan ulasan tersebut, peneliti memanfaatkan biji dari buah kelor yang telah tua dan kering tadi sebagai koagulan. Selain itu, menurut Risianto (2009) keuntungan penggunaan biji kelor sebagai koagulan dalam pengolahan air yaitu caranya sangat mudah, tidak berbahaya bagi kesehatan, ekonomis dan kualitas air menjadi lebih baik (jernih).

Penggunaan biji kelor sebagai biokoagulan untuk mengurangi kadar logam dalam air, juga didasarkan pada hasil penelitian sebelumnya, antara lain: Serbuk biji kelor dapat menurunkan kadar timbal, kekeruhan dan intensitas warnanya (Nugroho, et. al., 2014). Biji kelor terbukti dapat digunakan sebagai koagulan dalam menurunkan kadar ion logam kadmium(II) (Zulkarnain, 2016). Biji kelor terbukti dapat digunakan sebagai koagulan Fosfat dalam limbah cair rumah sakit (Khasanah, 2008). Biji kelor juga dapat digunakan sebagai koagulan dalam menurunkan kekeruhan, kadar ion besi dan mangan dalam air (Srawaili, 2007).

Bahan-bahan koagulan alami seperti biji kelor dimungkinkan dapat menggantikan bahan koagulan sintetis, sehingga permasalahan yang dihadapi oleh masyarakat dan industri dapat teratasi. Disisi lain pemanfaatan biji kelor yang selama ini jarang digunakan tentunya akan membantu meningkatkan perekonomian petani yang menanam pohon kelor (Hidayat, 2009). Berdasarkan kajian tersebut, peneliti berinisiatif untuk memanfaatkan biji kelor sebagai koagulan alami dalam menurunkan kadar besi dan kalsium dengan menvariasikan konsentrasi biji kelor dan waktu pengendapannya, untuk dapat mendapatkan hasil yang lebih maksimal (Suherman dan Sumawijaya, 2013).

\section{Metode Penelitian}

Rancang Bangun

Pada penelitian ini mengambil sampel satu liter air sungai yang keruh untuk setiap percobaan. Sebelumnya air diukur dahulu dengan 
turbidimeter. Ada tiga percobaan, percobaan pertama adalah memasukkan 0,5 gram bubuk biji kelor ke dalam satu liter sampel air. Percobaan kedua adalah memasukkan 0.2 gram bubuk biji kelor ke dalam satu liter sampel air. Percobaan ketiga adalah memasukkan 0.1 gram bubuk biji kelor ke dalam satu liter sampel air.

Air tersebut ditempatkan pada botol plastik bervolume 1 liter. Biji kelor yang telah ditumbuk dimasukkan ke dalam botol tersebut dan diaduk dengan cara tertentu. Setelah didiamkan beberapa waktu, pada botol akan tampak dua lapisan yaitu kotoran berada di atas dan air berada di bawah. Air yang sudah dijernihkan diukur lagi dengan turbidimeter.

$$
\text { Penelitian penjernihan air ini }
$$

menggunakan air sungai Kaligarang yang mana sungai tersebut masih banyak digunakan masyarakat disekitarnya sebagai air untuk mencuci alat makan dan lain-lain. Dilihat dari kondisi sungai yang sudah tidak layak digunakan sebagai sumber air bersih.

Alat dan Bahan

Alat

- Gelas Beker 1000 mL

- Batang pengaduk

- pH meter

- Gelas ukur 1000 mL

- Kertas saring

- lumping dan alu

Bahan

- Biji kelor

- Daun kelor

- Benalu teh

- Kaporit

- Arang aktif

- Pasir bersih

- Air kotor
Prosedur Kerja

1. Penjernihan air dengan biji kelor

- Menyiapkan gelas beker ukuran $1000 \mathrm{ml}$ sebanyak 4 buah

- Mengisi gelas beker sesuai petunjuk berikut:

Gelas beker $\mathrm{A}=$ Air kotor $650 \mathrm{ml}+$ serbuk biji kelor 0,5 gram

Gelas beker B = Air kotor $650 \mathrm{ml}+$ serbuk biji kelor 0,5 gram + pasir bersih 0,5 gram

Gelas beker $\mathrm{C}=$ Air kotor $650 \mathrm{ml}+$ serbuk biji kelor 0,5 gram + pasir bersih 0,5 gram + arang aktif 0,5 gram

Gelas beker D = Air kotor $650 \mathrm{ml}+$ serbuk biji kelor 0,5 gram + pasir bersih 0,5 gram + arang aktif 0,5 gram + kaporit 1 sendok

2. Penjernihan air dengan daun kelor

- Menyiapkan gelas beker ukuran $1000 \mathrm{ml}$ sebanyak 4 buah

- Mengisi gelas beker sesuai petunjuk berikut:

Gelas beker A = Air kotor $650 \mathrm{ml}+$ serbuk daun kelor 0,5 gram

Gelas beker B = Air kotor $650 \mathrm{ml}+$ serbuk daun kelor 0,5 gram + pasir bersih 0,5 gram

Gelas beker $\mathrm{C}=$ Air kotor $650 \mathrm{ml}+$ serbuk daun kelor 0,5 gram + pasir bersih 0,5 gram + arang aktif 0,5 gram

Gelas beker D = Air kotor $650 \mathrm{ml}+$ serbuk daun kelor 0,5 gram + pasir bersih 0,5 gram + arang aktif 0,5 gram + kaporit 1 sendok

3. Penjernihan air dengan benalu teh

- Menyiapkan gelas beker ukuran $1000 \mathrm{ml}$ sebanyak 4 buah

- Mengisi gelas beker sesuai petunjuk berikut:

Gelas beker $\mathrm{A}=$ Air kotor $650 \mathrm{ml}+$ serbuk benalu teh 0,5 gram

Gelas beker B = Air kotor $650 \mathrm{ml}+$ serbuk benalu teh 0,5 gram + pasir bersih 0,5 gram Gelas beker $\mathrm{C}=$ Air kotor $650 \mathrm{ml}+$ serbuk benalu teh 0,5 gram + pasir bersih 0,5 gram + arang aktif 0,5 gram 
Gelas beker $\mathrm{D}=$ Air kotor $650 \mathrm{ml}+$ serbuk benalu teh 0,5 gram + pasir bersih 0,5 gram + arang aktif 0,5 gram + kaporit 1 sendok

4. Mengaduk selama 30 detik dan dibiarkan selama 1 hari

5. Mengamati tingkat kejernihan air pada selang waktu 6, 12, dan 24 jam

6. Setelah didiamkan selama 1 hari, menyaring air dengan kertas saring

7. Mengamati tingkat kejernihannya

8. Mengukur $\mathrm{pH}$ nya dan mengidentifikasi baunya

\section{Hasil dan Pembahasan}

Koagulasi dan flokulasi dipengaruhi oleh beberapa faktor antara lain, konsentrasi atau dosis koagulan, kecepatan pengadukan, derajat keasaman $(\mathrm{pH})$, waktu pengendapan, kekeruhan, jenis koagulan dan temperatur (Hammer, 2007). Penelitian ini dilakukan untuk mengetahui efektifitas koagulan biji kelor dalam mengurangi konsentrasi besi (Fe) dan kalsium (Ca) dengan memvariasikan dua faktor di atas, yaitu konsentrasi biji kelor dan waktu pengendapan sampel.

Penghalusan biji dan daun kelor bertujuan untuk memperbesar luas pemukaan biji kelor sehingga semakin besar intensitas tumbukan antara besi dan kalsium dengan biji dan daun kelor. Biji dan daun kelor diinteraksikan dengan sampel yang mengandung ion logam, kemudian diaduk dengan waktu pengadukan cepat 30 detik dan 5 menit pengadukan lambat. Pengadukan cepat bertujuan untuk memberikan konstribusi tumbukan antara koloid yang mengandung ion logam dan koagulan sehingga terjadi destabilisasi koloid yang bermuatan positif oleh koagulan kelor yang bermuatan negatif. Pengadukan lambat bertujuan untuk memberikan waktu untuk terjadi proses flokulasi yaitu terbentuknya flok-flok yang lebih besar sehingga membentuk endapan (Zulkarnain, 2008). Kemudian setelah diperoleh konsentrasi optimum biji dan daun kelor, maka dilakukan variasi waktu penjernihan sampel yaitu selama 6, 12 dan 24 jam.

Gambar 1. Penjernihan air dengan (a) daun kelor, (b) biji kelor dan (c) benalu teh setelah 6 jam

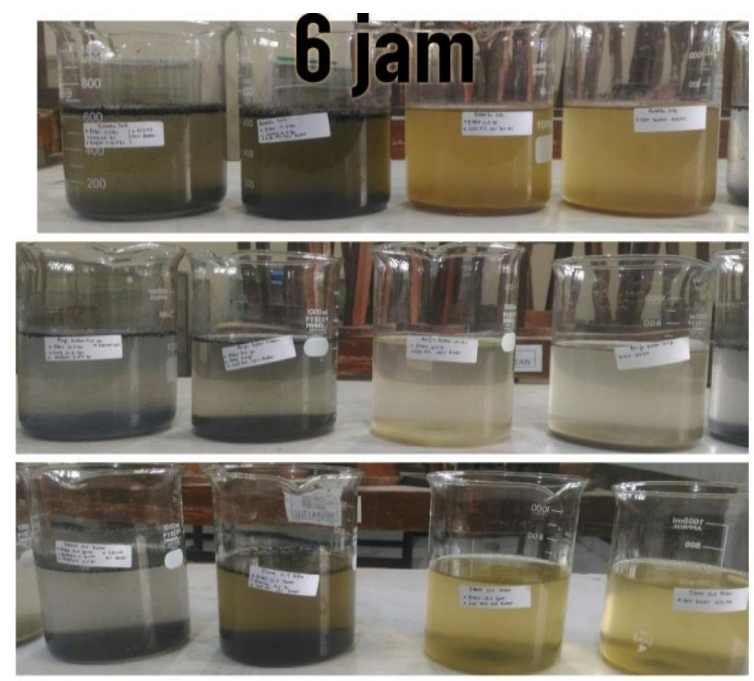

Gambar 2. Penjernihan air dengan (a) daun kelor, (b) biji kelor dan (c) benalu teh setelah 12 jam

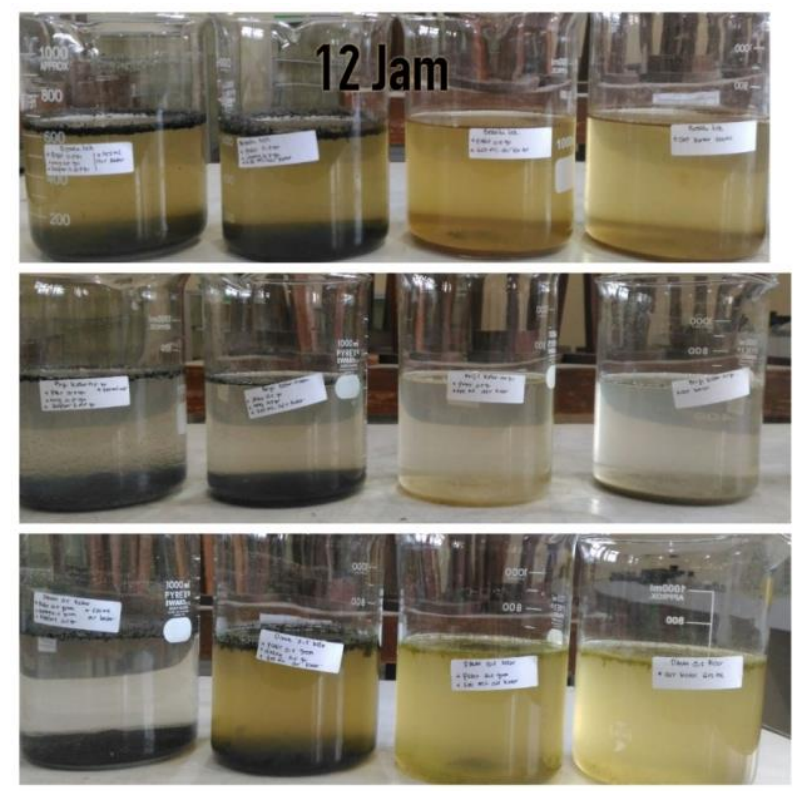


Gambar 3. Penjernihan air dengan (a) daun kelor, (b) biji kelor dan (c) benalu teh setelah 24 jam

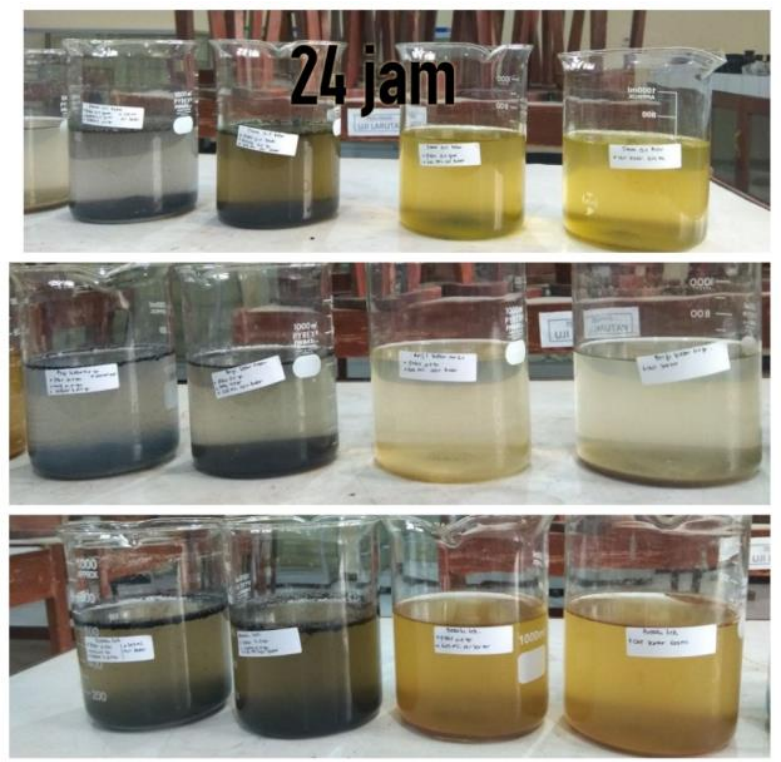

Berdasarkan hasil penelitian penjernihan Air sungai dengan bubuk biji kelor didapatkan hasil 8,67 NTU untuk bubuk biji kelor 0.5 gram , 4.29 NTU untuk biji kelor 0.2 gram dan 3.07 NTU dengan biji kelor 0.1 gram. Hal ini artinya dalam praktikum penjernihan air dengan bubuk biji kelor yang telah dilakukan kualitas air bertambah jernih dan masih memenuhi persyaratan air bersih yang diperbolehkan. Dapat disimpulkan pula bahwa dalam penjernihan air 1 liter lebih efektif / idealnya dengan 0.1 gram bubuk biji kelor.

Tabel 1. Hasil Pengukuran pH

\begin{tabular}{cccc}
\hline $\begin{array}{c}\text { Gelas } \\
\text { Beker }\end{array}$ & $\begin{array}{c}\text { Daun } \\
\text { Kelor }\end{array}$ & Biji Kelor & $\begin{array}{c}\text { Benalu } \\
\text { teh }\end{array}$ \\
\hline A & 7,6 & 7,3 & 7,3 \\
\hline B & 7,2 & 7,1 & 7,2 \\
\hline C & 7,3 & 7,0 & 7,4 \\
\hline D & 7,6 & 7,7 & 7,5 \\
\hline
\end{tabular}

\section{Kesimpulan}

Penelitian ini menggunakan biji dan daun kelor sebagai bahan koagulan untuk penjernihan air dengan metode koagulasi dan flokulasi. Untuk mengetahui apakah air tersebut telah memenuhi syarat kualitas air bersih, salah satu indikatornya adalah mengukur tingkat kekeruhan.

Pemanfaatan biji dan daun kelor sebagai penjernih air adalah salah satu cara cukup efektif dan efisien karena bahan baku dan teknik penjernihannya tidak rumit, sederhana dan murah. Berdasarkan hasil penelitian penjernihan air dengan biji kelor yang di lakukan, didapatkan hasil yang lebih jernih dibandingkan menggunakan daun kelor dan benalu teh. Maka dapat disimpulkan bahwa penggunaan biji kelor untuk penjernihan air efektif karena biji kelor bersifat sebagai koagulan dalam pengendapan flok.

\section{Daftar Pustaka}

Chandra, B. 2015. Pengantar kesehatan lingkungan. Jakarta: EGC.

Dinora, G. Q., \& Purnomo, A. 2013. Penurunan Kandungan Zat Kapur Dalam Air Tanah Dengan Menggunakan Media Zeolit Alam Dan Karbon Aktif Menjadi Air Bersih. Jurnal Tekhnik POMITS, 2(2), 78-82.

Fauzi, L. 2010. Pengaruh pemberian rebusan daun kelor (moringa oleifera) terhadap kadar asam urat darah. Skripsi, Medan: FK-UISU Medan.

Hammer. 2007. Water And Wastewater Technology (Second ed.). New York: John Wiley and Son Inc.

Hidayat, S. 2009. Protein Biji Kelor Sebagai Bahan Aktif Penjernihan Air. Journal of Biospecies, 2(2), 12-17.

Khasanah, U. 2008. Efektifitas Biji Kelor (Moringa Oleifera Lamk) Sebagai Koagulan Fosfat Dalam Limbah Cair Rumah Sakit. Skripsi, Malang: FST-UIN Malang

Nugrahayu, Q., \& Purnomo, A. 2013. Penurunan Kandungan Zat Kapur Dalam Air Tanah Dengan Menggunakan Filter Media Zeolit 64 
Alam Dan Pasir Aktif Menjadi Air Bersih. Jurnal teknik POMITS, 2(2), 122-126.

Nugroho, B. A., Miswadi, S. S., \& Santosa, N. B. 2014. Penggunaan Serbuk Biji Kelor Untuk Menurunkan Kadar $\mathrm{Pb}$, Kekeruhan Dan Intensitas Warna. Indonesian Journal of Chemical Science, 3(3), 174-178.

Risianto, N. 2009. Pengaruh Variasi Konsentrasi Ekstrak Serbuk Biji Kelor (Moringa Oliefera Lamk) Terhadap Penurunan Kesadahan Air Sumur Artetis. Skripsi, Semarang: Universitas Muhammadiyah Semarang.

Sada, J. T., \& Tanjung, R. H. R. 2010. Keragaman Tumbuhan Obat Tradisional Di Kampung Nansfori Distrik Supiori Utara Kabupaten Supiori Papua. Jurnal Biologi Papua, 2(2), 39-46

Srawaili, N. 2007. A Caladium Seed (Moringa Oleifera) Biocoagulan Efectivity To Decrease Ferum (Fe) And Manganese (Mn) Concentration From Aqueous Solution. Journal Environmental Science, 4(57), 35493556.

Suherman, D., \& Sumawijaya, N. 2013. Menghilangkan Warna Dan Zat Organik Air Gambut Dengan Metode Koagulasi-Flokulasi Suasana Basa. Jurnal Riset Geologi dan Pertambangan, 23(2), 125-138.

Utami, F., Rumhayati, B., \& Masruri. 2013. Application of Moringa Oleifera Seed Powder For Coagulating Of Iron(Iii) On Local Water Resources. Journal Pure App Chem Res, 2(3), 122-125.

Zulkarnain. 2016. Efektifitas Biji Kelor (Moringa Oleifera Lamk) Dalam Mengurangi Kadar Kadmium(II). Skripsi, Malang: FST UIN Malang. 